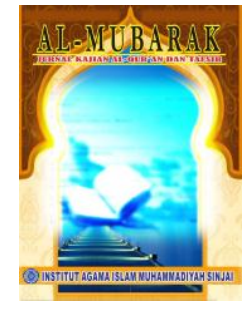

\title{
VIRUS CORONA DALAM PERSPEKTIF SUNNAH
}

\author{
Firdaus $^{1}$ \\ ${ }^{1}$ Institut Agama Islam Muhammadiyah Sinjai \\ E-mail:doktorfirdaus@gmail.com, Tlp:+628114188997
}

\begin{abstract}
Abstrak
Hadis menjelaskan tentang wabah dengan istilah thaa'uun. Istilah ini mencakup semua bentuk virus atau wabah yang dapat menular atau mewabah kepada setiap orang. Melalui kata thaa'uun, hadis-hadis Nabi Saw tentang virus corona dapat ditelusuri. Ini menunjukkan bahwa di masa Nabi dan sahabat telah terjadi kondisi yang serupa dengan kondisi yang menimpa hampir semua negara saat ini. Menurut hadis Nabi Saw, salah satu cara menghindari atau memutus mata rantai merebak atau semakin meluasnya wabah itu adalah lockdown atau isolasi diri, termasuk stay home. Keluar rumah dibolehkan jika ada kepentingan tertentu dan mendesak, itupun harus hati-hati, menggunakan masker, dan menjaga jarak dengan orang lain atau social distancing. Illat gugurnya kewajibah shalat jum'at dan shalat berjama'ah adalah berkumpul dalam satu tempat saat Covid-19 dapat menular dan menyebar, karena hal ini dapat menambah dan dianggap dapat memperluas penyebaran wabah Covid-19 tersebut. Dan jika hal ini terjadi terus menerus, maka korban akan terus bertambah dan mata rantai penyebaran Covid-19 sangat sulit untuk dihentikan. Karena itu, seluruh ibadah yang melibatkan banyak orang dan berkumpul dalam suatu tempat harus dihindari, termasuk shalat jum'at, shalat wajib, tarwih, dan 'Id secara berjama'ah. Pelaksanaan Ibadah ini, sebaiknya dilaksanakan di rumah masing-masing sampai terhentinya penyebaran Covid19.
\end{abstract}

Kata Kunci: Virus Corona, Sunnah

\section{Pendahuluan}

Fenomena penyebaran wabah coronavirus disease (covid-19) yang merebak di berbagai negara termasuk di Indonesia merupakan pandemi virus yang mengancam kehidupan manusia. Akibat covid-19 yang telah menjangkiti banyak orang dan mengakibatkan banyak korban, yaitu ratusan ribu orang terinfeksi positif dan ribuan orang meninggal dunia di sejumlah negara, termasuk di Indonesia (Lamp. Edaran PP Muhammadiyah, 2020). Virus ini menjadi pandemi sebagaimana telah ditetapkan oleh WHO pada tanggal 11 Maret 2020, merujuk lebih dari 118 ribu kasus infeksi di lebih dari 110 negara dan wilayah di seluruh dunia dengan resiko penyebaran global lebih luas (Khadijah Nur Azizah, 2020). Penyebarannya yang begitu cepat melalui proses penularan yang mudah dan tidak mudah dideteksi serta sikap acuh sebagian masyarakat terhadap penyebaran dan 


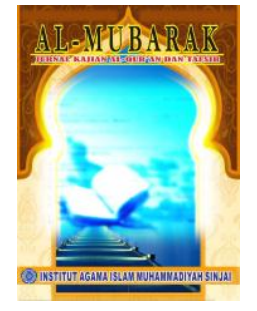

Al-MUBARAK

Jurmall Kajian Al-Quran \& Tafsir

Volume 5, No. 1, 2020

P-ISSN: 2548-7248

E-ISSN: 2715-5692

Homepage : http://journal.iaimsinjai.ac.id/indeks.php/al-mubarak

mudharat yang ditimbulkan oleh covid-19 merupakan penyebab merebaknya lebih cepat dan lebih luas virus tersebut.

Berdasarkan pernyataan resmi WHO, sebagaimana dikutip dalam Lampiran Edaran PP Muhammadiyah Nomor 02/EDR/1.0/E/2020, Tanggal 29 Rajab 1441 H/24 Maret 2020, bahwa covid 19 telah menjadi pandemi dan kriteria Kejadian Luar Biasa (KLB) yang mengacu pada keputusan Direktur Jenderal Pemberantasan Penyakit Menular dan Penyehatan Lingkungan Pemukiman Kementerian Kesehatan RI No. 451/91, tentang Pedoman Penyelidikan dan Penanggulangan Kejadian Luar Biasa bahwa suatu kejadian dinyatakan luar biasa jika ada beberapa unsur, antara lain: 1. Timbulnya suatu penyakit menular yang sebelumnya tidak ada atau tidak dikenal; 2. Peningkatan kejadian penyakit/kematian terus menerus selama kurun waktu berturut-turut menurut jenis penyakitnya (jam, hari dan minggu) (Lamp. Edaran PP Muhammadiyah, 2020). Dengan demikian, kondisi saat ini telah memasuki fase darurat Covid-19 berskala global.

Berdasarkan hal tersebut, baik MUI maupun PP Muhammadiyah telah menindaklanjuti keputusan dan kondisi tersebut dengan mengeluarkan Fatwa tentang ibadah seperti shalat Jumat dapat diganti dengan salat zuhur di kediaman masing-masing, karena shalat jum'at merupakan ibadah wajib yang melibatkan banyak orang sehingga berpeluang terjadinya penularan virus secara massal. Selengkapnya Keputusan MUI tersebut dapat dilihat pada Surat Keputusan Nomor 14 tahun 2020 yang dirilis pada Senin (16/03) menyebut: (1) Dalam hal ia berada di suatu kawasan yang potensi penularannya tinggi atau sangat tinggi berdasarkan ketetapan pihak yang berwenang maka ia boleh meninggalkan salat Jumat dan menggantikannya dengan salat zuhur di tempat kediaman, serta meninggalkan jamaah salat lima waktu/rawatib, Tarawih, dan Ied di masjid atau tempat umum lainnya; (2) Dalam hal ia berada di suatu kawasan yang potensi penularannya rendah berdasarkan ketetapan pihak yang berwenang maka ia tetap wajib menjalankan kewajiban ibadah sebagaimana biasa dan wajib menjaga diri agar tidak terpapar virus Corona, seperti tidak kontak fisik langsung (bersalaman, berpelukan, cium tangan), membawa sajadah sendiri, dan sering membasuh 


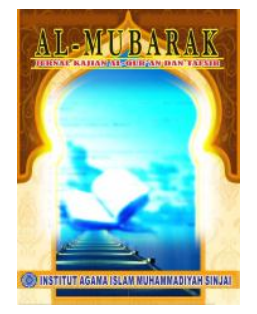

Al-MUBARAK

Jurmall Kajian Al-Quran \& Tafsir

Volume 5, No. 1, 2020

P-ISSN: 2548-7248

E-ISSN: 2715-5692

Homepage : http://journal.iaimsinjai.ac.id/indeks.php/al-mubarak

tangan dengan sabun; (3) Dalam kondisi penyebaran Covid-19 tidak terkendali di suatu kawasan yang mengancam jiwa, umat Islam tidak boleh menyelenggarakan salat jumat di kawasan tersebut, sampai keadaan menjadi normal kembali dan wajib menggantikannya dengan salat zuhur di tempat masing-masing; (4) Dalam kondisi penyebaran Covid-19 tidak terkendali di suatu kawasan yang mengancam jiwa, tidak boleh menyelenggarakan aktivitas ibadah yang melibatkan orang banyak dan diyakini dapat menjadi media penyebaran Covid-19, seperti jamaah salat lima waktu/ rawatib, shalat Tarawih dan Ied di masjid atau tempat umum lainnya, serta menghadiri pengajian umum dan majelis taklim; dan (5) Pengurusan jenazah (tajhiz janazah) terpapar Covid-19, terutama dalam memandikan dan mengkafani harus dilakukan sesuai protokol medis dan dilakukan oleh pihak yang berwenang, dengan tetap memperhatikan ketentuan syariat. Sedangkan untuk mensalatkan dan menguburkannya dilakukan sebagaimana biasa dengan tetap menjaga agar tidak terpapar COVID-19 (Keputusan MUI, 2020).

Demikian pula Fatwa yang dikeluarkan oleh Ketua Umum Muhammadiyah, Haedar Nashir pada 24 Maret 2020, bahwa fenomena penyebaran wabah Covid19 yang meluas termasuk di Indonesia merupakan pandemi yang mengancam kehidupan manusia, sehingga ibadah yang melibatkan banyak orang dan berkumpul dalam suatu tempat ditiadakan dengan menggantinya dengan ibadah secara individu di rumah masing-masing, karena berkumpul dalam suatu tempat dapat menambah dan dianggap dapat memperluas penyebaran wabah Covid-19 tersebut.

Dalam hadis Nabi, istilah Covid-19 tidak disebutkan secara khusus, tapi peristilahannya bersifat umum, yaitu thaa'un. Istilah ini mencakup semua bentuk virus atau penyakit yang dapat menular atau mewabah kepada setiap orang. Ini menunjukkan bahwa di masa Nabi dan sahabat telah terjadi kondisi yang serupa dengan kondisi yang menimpa hampir semua negara saat ini, yaitu Covid-19. Lalu bagaimana pelaksanaan ibadah yang pelaksanaannya melibatkan dan mengumpulkan banyak orang (berjamaah) seperti shalat jum'at, 'idul fithri, 'idul adha dan shalat berjama'ah? Adakah hadis atau petunjuk Nabi yang menjelaskannya? 


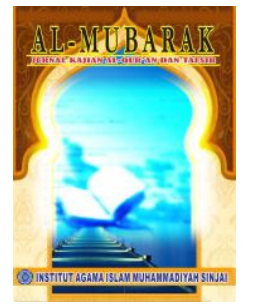

Al-MUBARAK

Jurmall Kajian Al-Quran \& Tafsir

Volume 5, No. 1, 2020

P-ISSN: 2548-7248

E-ISSN: 2715-5692

Homepage : http://journal.iaimsinjai.ac.id/indeks.php/al-mubarak

\section{Metode}

Penelitian ini adalah penelitian kepustakaan (library research) dengan jenis kualitatif. Penelitian kepustakaan yang dilakukan berfungsi untuk menelusuri, mendeskripsikan, serta menganalisa hadis-hadis tentang wabah corona. Adapun pengumpulan datanya dilakukan dengan cara menelusuri sumber primer dari literatur-literatur kitab hadis seperti kutub as-sittah dan kutub as-sab'ah baik secara manual maupun digital. Setelah data terkumpul, berikutnya analisis data yang digunakan dalam penelitian ini adalah analisis isi (content analysis). Analisis data jenis ini dilakukan sebagai upaya untuk mendapatkan jawaban dari 'bagaimana' hadis/sunnah mengulas tentang wabah corona.

\section{Pembahasan}

\subsection{Pengertian beberapa Istilah Wabah, Epidemi, Pandemi dan Tha'un}

Menurut Kamus Besar Bahasa Indonesia, wabah adalah penyakit menular yang berjangkit dengan cepat, menyerang sejumlah besar orang di daerah yang luas (Depdikbud, 1993: 1122). Sedangkan arti epidemi hampir sama dengar arti wabah, yaitu penyakit menular yang berjangkit dengan cepat di daerah yang luas dan menimbulkan banyak korban (Depdikbud, 1993: 267). Bedanya kedua istilah tersebut terletak pada dampak yang ditimbulkan oleh penyakit menular atau virus tersebut. Wabah hanya sampai pada penularan, sedangkan epidemi sudah menimbulkan banyak korban.

Selanjutnya, arti pandemi adalah wabah yang berjangkit serempak di manamana, meliputi daerah geografi yang luas (Depdikbud, 1993: 1122). Arti ini hampir sama atau sama dengan arti wabah dan epidemi. Bedanya dengan arti pandemi adalah penjangkitannya yang terjadi secara serempak dan meluas di berbagai daerah. Di samping itu, kedua kata tersebut memiliki rujukan tentang skala. Karena, keduanya sering dipergunakan oleh lembaga yang mengurus kesehatan masyarakat, baik di tingkat negara maupun dunia.

Epidemi biasa digunakan untuk menyebut wabah dalam skala yang besar. Sedangkan pandemi biasa digunakan untuk merujuk ke wabah yang memiliki skala global. 


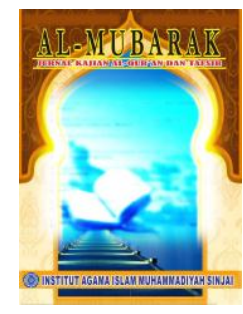

\section{Al-MUBARAK}

Jurmall Kajian Al-Quran \& Tafsir

Volume 5, No. 1, 2020

P-ISSN: 2548-7248

E-ISSN: 2715-5692

Homepage : http://journal.iaimsinjai.ac.id/indeks.php/al-mubarak

Adapun istilah thaa'un berasal dari kata tha'ana, terdiri dari huruf tha, 'ain dan nun, dengan makna dasarnya adalah mencucuk atau mematuk sesuatu dengan terus menerus (Ibnu Faris, 1994: 619). Makna ini bersifat umum karena masih meliputi segala hal yang dapat mematuk atau menyakiti seseorang secara berkesinambungan. Makna lain kata tersebut adalah al-wabaa', yaitu wabah atau penyakit menular, atau pes (Fairuz Abadi, 1996: 1219). Arti ini juga masih bersifat umum, karena meliputi seluruh penyakit atau virus yang menular dan dapat menjangkiti siapa saja, termasuk civid-19. Lebih spesifik, makna kata thaa'un dapat dilihat dalam Kamus al_Munjid al-Abjadiy, yaitu wabah atau epidemi yang berkaitan dengan demam/virus yang keras dan tersembunyi serta merusak, menempel dan menyebar. Arti ini lebih jelas lagi dan khusus karena telah menyebutkan salah satu jenis wabah dan sifat-sifatnya. Dengan demikian dapat dipahami bahwa civid-19 adalah salah satu jenis thaa'un atau wabah yang dapat menjangkiti dan menulari siapa pun secara berkesinambungan.

Kata atau istilah thaa'un inilah yang dapat dilihat dalam hadis-hadis Nabi Saw. dan juga merupakan petunjuk untuk menelusuri hadis-hadis Nabi Saw yang menjelaskan tentang semua penyakit menular, termasuk civid-19.

\subsection{Hadis-Hadis Thaa'uun (Wabah)}

Hadis-hadis Nabi Saw yang menjelaskan tentang Thaa'uun atau Wabah banyak, baik hadis yang diriwayatkan oleh Imam Bukhari, Imam Muslim ataupun periwayat lainnya. Redaksi dan kandungan makna riwayat-riwayat tersebut hampir atau bahkan sama. Berikut ini, redaksi hadis dimaksud adalah (AlBukhari):

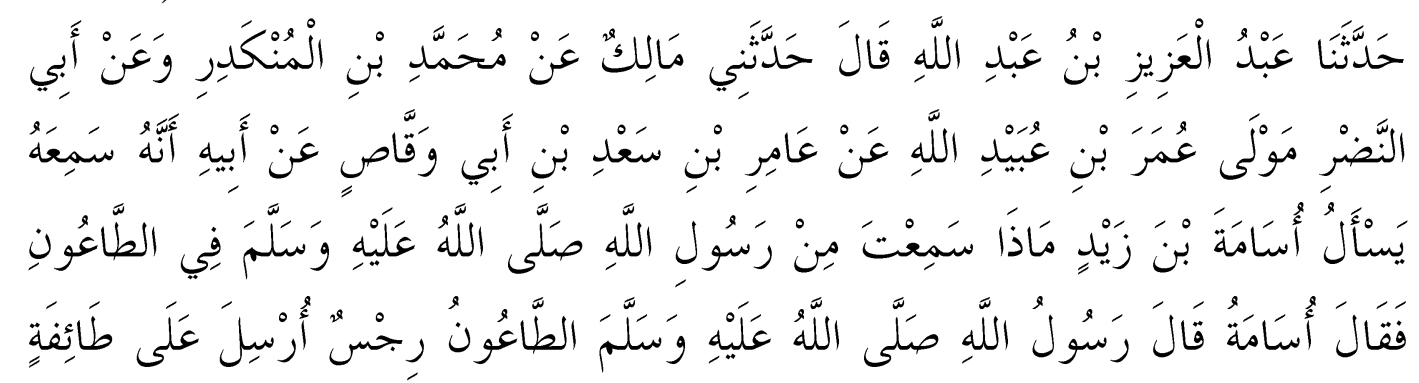




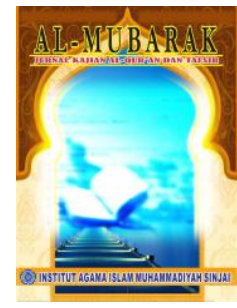

\section{Al-MUBARAK}

Jurnal Kajian Al-Quran \& Tafsir

Volume 5, No. 1, 2020

P-ISSN: 2548-7248

E-ISSN: 2715-5692

Homepage : http://journal.iaimsinjai.ac.id/indeks.php/al-mubarak

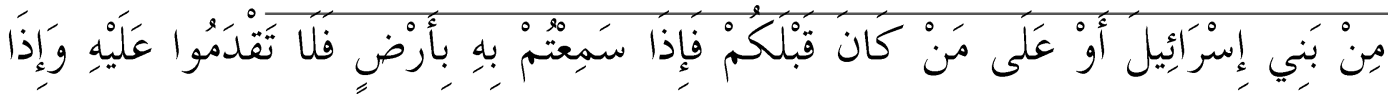

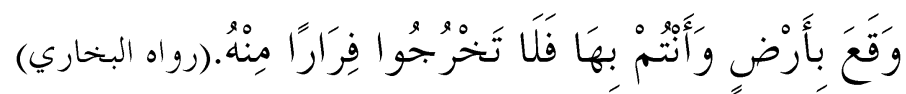

Artinya:

"Abdul Aziz bin Abdillah telah menceriterakan kepada kami bahwa Malik telah meriwayatkan dari Muhammad bin al-Munkadir dan dari Abi alNadhr, dari 'Aamir bin Sa'ad bin Abi Waqqaash dari Bapaknya bahwa ia telah mendengar dan bertanya kepada Usaamah bin Zaid: Apa yang anda telah dengar dari Rasulillah Saw tentang thaa'uun, lalu Usaamah menjawab bahwa Rasulullah Saw bersabda bahwa thaa'uun adalah najis atau wabah yang telah dikirim kepada suatu kaum dari Bani Isra'il atau kepada orangorang sebelum kamu, maka jika kalian mendengar bahwa di suatu tempat terdapat wabah (virus), maka janganlah mendatangi tempat tersebut, dan kalian yang berada di tempat tersebut maka janganlah keluar dari tempat itu dengan segera". (HR. Bukhari)

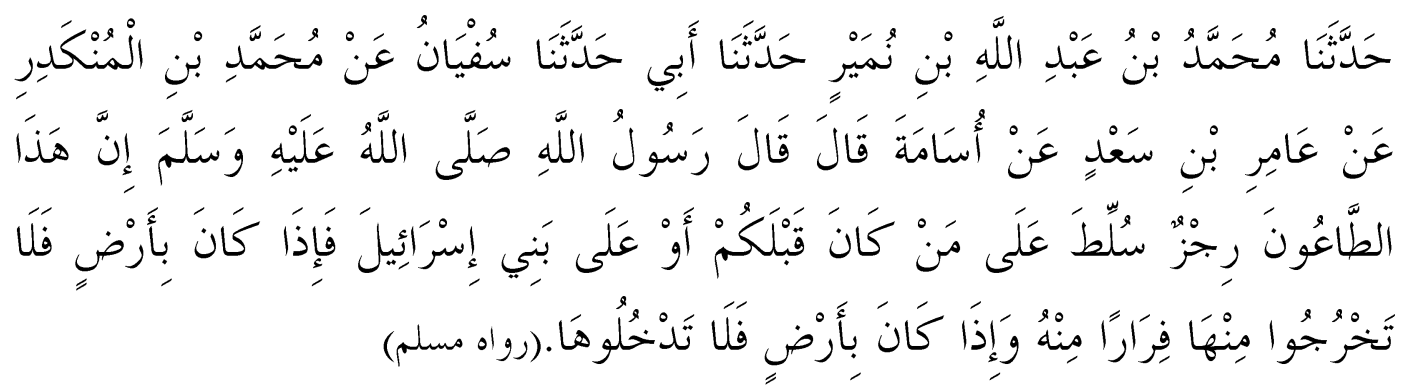

Artinya:

" Muhammad bin Abdillah bin Numair telah menceriterakan kepada kami bahwa Bapak saya telah menceriterakan kepada kami bahwa Sofyan telah meriwayatkan dari Muhammad bin al-Munkadir dari 'Aamir bin Sa'ad dari Usaamah berkata bahwa Rasulullah Saw bersabda: sesungguhnya thaa'uun ini adalah najis atau wabah yang ditimpakan kepada orang-orang sebelum kamu atau kepada Bani Israil, maka jika kalian berada di tempat tersebut, maka janganlah kalian keluar dari tempat tersebut dengan segera dan apabila kalian berada di luar tempat itu, maka janganlah kalian masuk ke tempat tersebut". (HR. Muslim)

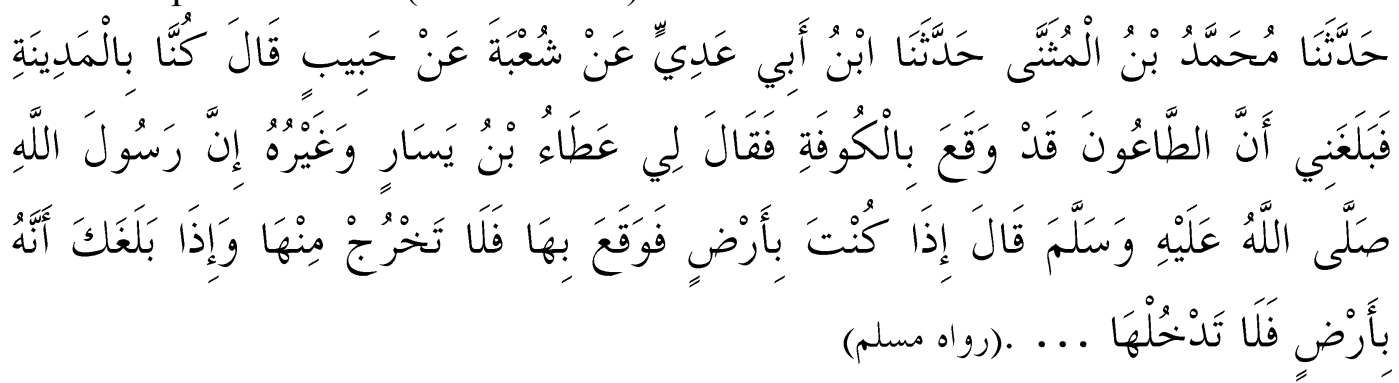

Artinya:

"Muhammad bin al-Mutsanna telah menceriterakan kepada kami bahwa Ibnu Abi 'Adiy telah menceriterakan dari Syu'bah dari Habib berkata bahwa kami berada di Madinah kemudian disampaikan kepada saya bahwa 


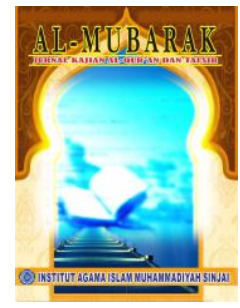

\section{Al-MUBARAK}

Jurmall Kajian Al-Quran \& Tafsir

Volume 5, No. 1, 2020

P-ISSN: 2548-7248

E-ISSN: 2715-5692

Homepage : http://journal.iaimsinjai.ac.id/indeks.php/al-mubarak

sesungguhnya thaa' uun atau wabah telah terjadi di Kufah, lalu 'Athaa' bin Yasaar dan yang lainnya berkata kepada saya bahwa sesungguhnya Rasulullah Saw pernah bersabda: apabila kamu berada di suatu daerah yang terjangkiti suatu wabah, maka janganlah kamu keluar dari daerah itu dan apabila anda berada di luar daerah itu, maka janganlah masuk ke wilayah itu. (HR. Muslim)

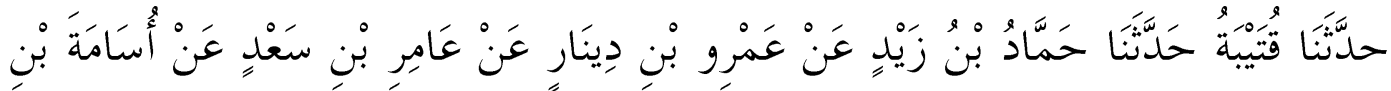

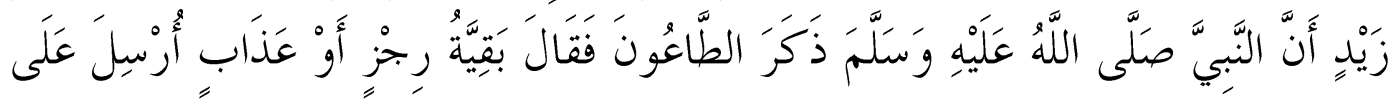

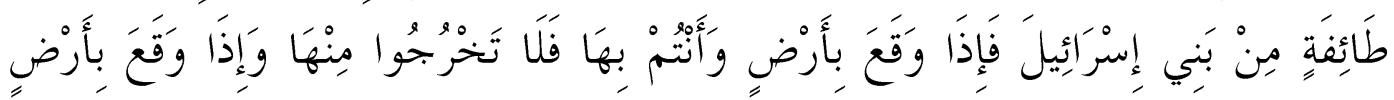

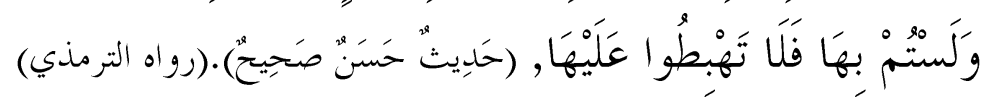

Artinya:

"Qutaibah telah menceriterakan kepada kami bahwa Hammaad bin Zaid telah meriwayatkan dari 'Amar bin Dinaar dari 'Aamir bin Sa'ad dari Usaamah bin Zaid bahwa sesungguhnya Nabi Saw pernah memgemukakan tentang thaa'uun, kemudian dia menyebutkan bahwa thaa'uun adalah sisa kotoran (wabah) atau azab yang ditimpakan kepada kaum Bani Israil, maka apabila terdapat wabah di suatu daerah dan kalian berada di wilayah tersebut, maka janganlah kalian keluar dari wilayah itu, dan apabila wabah itu terdapat di suatu daerah dan kalian tidak berada di tempat itu, maka janganlah kalian turun atau masuk ke wilayah tersebut. (HR. al-Turmudzy)

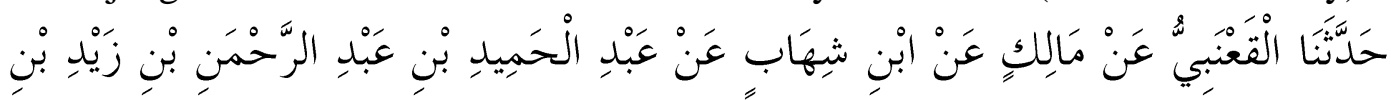

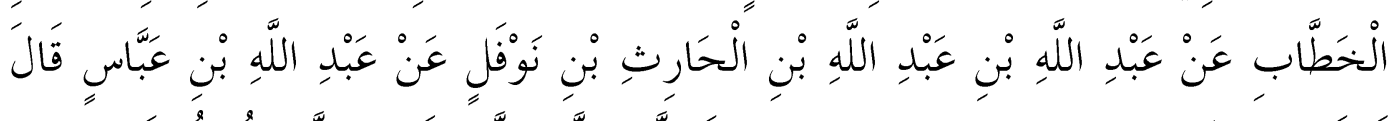

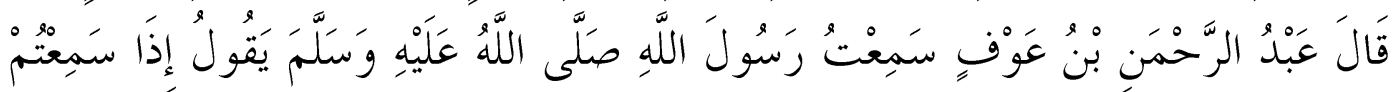

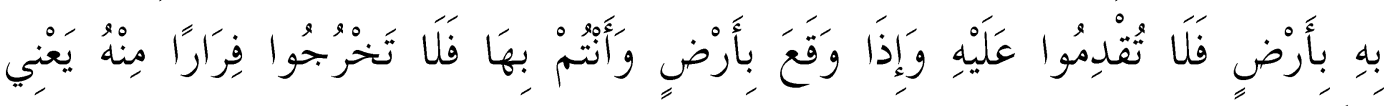

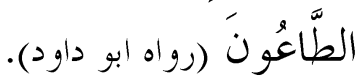

Artinya:

"Al-Qa'nabiy telah menceriterakan kepada kami dari Maalik, dari Ibnu Syihab dari 'Abd al-Hamid bin 'Abd al-Rahman bin Zaid bin al-Khaththab dari 'Abdillah bin 'Abdillah bin al-Haris bin Naufal dari 'Abdillah bin 'Abbas berkata bahwa 'Abd al-Rahman berkata: saya pernah mendengar Rasulullah Saw bersabda: jika kalian mendengar suatu informasi tentang suatu wabah yang terdapat di suatu daerah, maka janganlah kalian mendatangi atau masuk ke daerah tersebut dan apabila kalian berada di tempat itu, maka janganlah kalian keluar darinya. (HR Abu Daud).

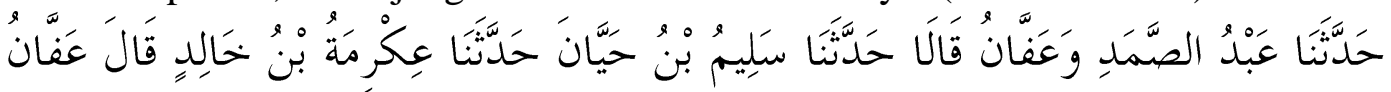

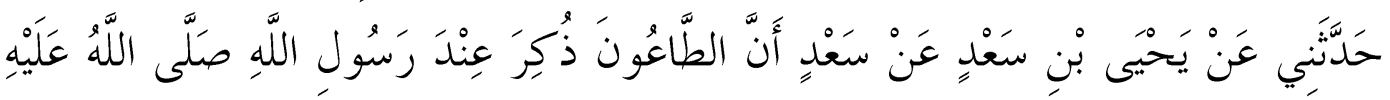




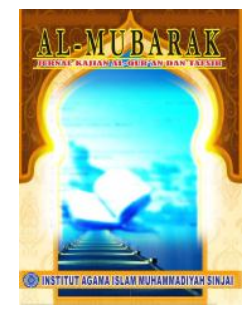

Al-MUBARAK

Jurnal Kajian Al-Quran \& Tafsir

Volume 5, No. 1, 2020

P-ISSN: 2548-7248

E-ISSN: 2715-5692

Homepage : http://journal.iaimsinjai.ac.id/indeks.php/al-mubarak

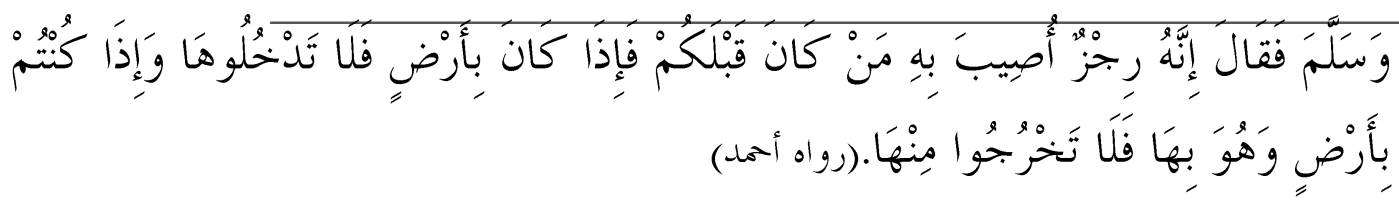

Artinya:"

Abd al-Shamad dan 'Affan telah menceriterakan kepada kami, keduanya berkata bahwa Salim bin Hayyan telah menceriterkan kepada kami bahwa 'Ikrimah bin Khalid pernah berkata bahwa 'Affan telah mencertiterakan kepada saya dari Yahya bin Sa'ad dari Sa'ad bahwa sesungguhnya thaa'uun telah dikemukakan oleh Rasulullah Saw bahwa ia adalah kotoran atau wabah yang ditimpakan kepada kaum sebelum kamu, maka apabila wabah itu terdapat di suatu daerah, maka janganlah kalian masuk ke daerah tersebut dan apabila kalian berada di dalam wilayah itu, maka janganlah kalian keluar dari daerah tersebut. (HR. Ahmad).

Ada lima riwayat hadis tentang thaa'uun yang dikemukakan di atas dan masih banyak riwayat lain yang memiliki makna yang sama dan kualitasnya tidak dapat diragukan. Ini menunjukkan bahwa wabah atau virus yang menimpa suatu kaum, telah terjadi sebelumya. Covid-19 yang merebak saat ini di hampir seluruh negara, bukanlah kejadian atau musibah baru, hanya bentuk wabahnya yang berbeda.

Ke lima hadis di atas menjelaskan bahwa thaa'uun adalah wabah penyakit menular dan covid-19 adalah salah satu bentuk thaa'uun atau wabah penyakit menular yang ditimpakan kepada suatu kaum untuk menjadi ujian dan peringatan bagi ummat manusia, agar mereka sadar dan kembali taat kepada Allah dan RasulNya. Sekaligus covid-19 merupakan ujian keimanan bagi hamba-Nya.

Kandungan lain dari ke lima hadis di atas adalah cara menangani penyakit menular atau thaa'uun seperti covid-19. Hadis tersebut menjelaskan bahwa salah satu cara menghindari atau memutus mata rantai merebak atau semakin meluasnya wabah itu adalah lockdown atau isolasi diri, termasuk stay home. Keluar rumah dibolehkan jika ada kepentingan tertentu dan mendesak, itupun harus hati-hati, menggunakan masker, dan menjaga jarak dengan orang lain atau social distancing. Semua cara-cara tersebut merupakan bentuk penghindaran diri dari merebaknya wabah, sebagaimana petunjuk hadis Nabi di atas.

Larangan Rasulullah Saw untuk tidak keluar dan tidak masuk pada daerah yang terkena wabah agar tidak tertular dan menularkan kepada orang lain. Apalagi jika seseorang telah mengetahui atau mengkhawatirkan dirinya telah terkena virus 


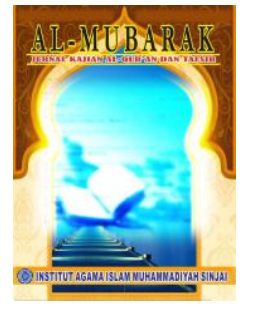

\section{AI-MUBARAK}

Jurmall Kajian Al-Quran \& Tafsir

Volume 5, No. 1, 2020

P-ISSN: 2548-7248

E-ISSN: 2715-5692

Homepage : http://journal.iaimsinjai.ac.id/indeks.php/al-mubarak

tersebut dan tetap bebas keluar masuk suatu wilayah atau di tempat umum dengan sengaja, tanpa keperluan yang mendesak, sehingga menyebabkan virus tersebut menular kepada orang lain dan menyebabkan orang tersebut meninggal karenanya, maka orang tersebut dianggap telah membunuhnya. Membunuh satu orang dengan sengaja, tanpa sebab, maka orang itu dianggap telah membunuh seluruh manusia. Bagitu pula sebaliknya, jika seseorang telah menjaga dan memelihara kehidupan orang lain, meskipun satu orang saja, maka dia seolah-olah telah memelihara kehidupan manusia semuanya. Hal ini didasarkan pada QS. AlMaidah: 32) berikut ini:

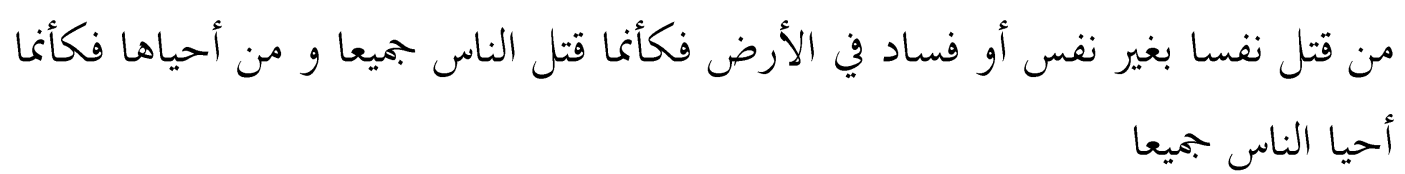

Terjemahnya:

"Barangsiapa yang membunuh seorang manusia, bukan karena orang itu (membunuh) orang lain, atau bukan kerena membuat kerusakan dimuka bumi ini, maka seakan-akan dia telah membunuh manusia seluruhnya. Dan barangsiapa yang memelihara kehidupan seorang manusia, maka seolaholah dia telah memelihara kehidupan manusia semuanya." (QS. Al-Maidah: 32).

Selain itu, dalam riwayat hadis lain yang semakna dengan ke-lima hadis di atas, juga menjelaskan bahwa wabah atau penyakit yang diturunkan oleh Allah Swt kepada manusia merupakan ujian atau cobaan, agar mereka sadar dan dapat kembali taat kepada Allah Swt. dalam riwayat tersebut dijelaskan sebagai berikut:

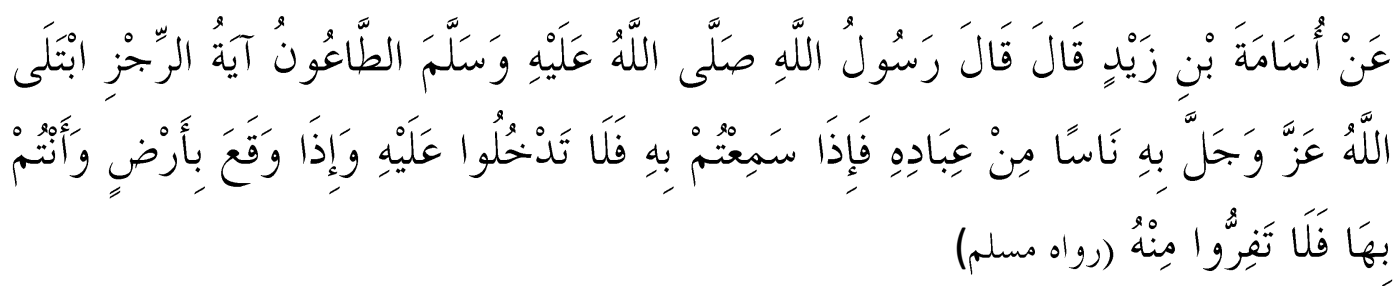

Artinya:

"Dari Usamah bin Zaid berkata bahwa Rasulullah Saw pernah bersabda bahwa wabah itu merupakan cobaan atau peringatan yang Allah Swt turunkan kepada hamba-Nya, maka apabila kalian mendengar bahwa wabah itu berjangkit di suatu daerah, maka janganlah kalian masuk ke daerah tersebut dan apabila wabah itu berjangkit di tempat kamu berada, maka janganlah kamu lari atau keluar dari tempat tersebut. (HR. Muslim).

Cobaan atau ujian berupa penderitaan yang Allah Swt turunkan kepada manusia, agar mereka sadar bahwa cobaan tersebut merupakan peringatan bagi 


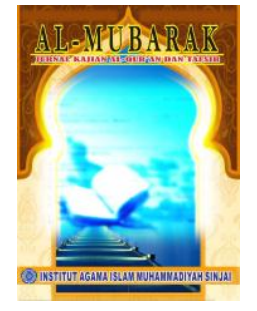

Al-MUBARAK

Jurmall Kajian Al-Quran \& Tafsir

Volume 5, No. 1, 2020

P-ISSN: 2548-7248

E-ISSN: 2715-5692

Homepage : http://journal.iaimsinjai.ac.id/indeks.php/al-mubarak

mereka yang selalu berbuat zhalim, untuk meninggalkan perbuatan dosa dan maksiat yang mereka biasa lakukan. Dan adapun bagi mereka yang beriman dan taat kepada Allah Swt, musibah berupa wabah itu merupakan ujian bagi keimanan mereka.

\subsection{Hukum Shalat Jum'at dan Shalat Berjama'ah di tengah Merebaknya Covid-19}

Hukum menghadiri shalat jum'at di masjid adalah fardhu 'ain bagi laki-laki. Secara tegas dan jelas, kewajiban ini dijelaskan di dalam QS. Al-Jum'ah: 9 dan Hadis Nabi Saw. Salah satu hadis Nabi Saw yang menjelaskan tentang kewajiban

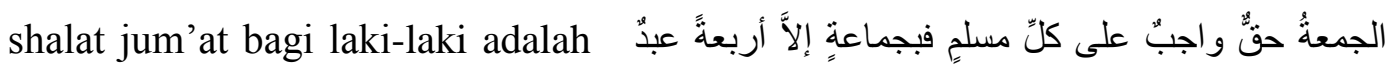
مملوكُّ أو امرأٌٌ أو صبيٌّ أو مريضٌ dengan berjama'ah kecuali empat orang, hamba sahaya, wanita, anak kecil, dan orang sakit.” (HR. Abu Daud no. 1067). Akan tetapi, terdapat beberapa kondisi ('udzur syar'i) yang menyebabkan kewajiban tersebut menjadi gugur, di antaranya adalah hujan deras, sakit, angin kencang, dan sebagainya.

Saat ini, situasi dalam keadaan memprihatinkan, covid-19 telah mewabah lebih 150 negara (teritori), dengan jumlah orang yang terinfeksi mencapai 179,112 dan dengan angka kematian sebanyak 7,426 orang. Situasi ini terjadi hanya dalam waktu sekitar 2,5 bulan saja. Karena itu, WHO telah memutuskan dan menetapkan kondisi pandemi, kondisi wabah yang paling gawat karena menunjukkan penyebaran yang sangat luas di seluruh dunia.

Melihat dan memperhatikan kondisi tersebut, maka diserukan untuk menghindari dan mengurangi aktivitas-aktivitas pengumpulan massa karena kerumunan massa tersebut dinilai sebagai faktor risiko tinggi terjadinya penularan. Tentu saja, kondisi itu akan mempengaruhi aktivitas ibadah kaum muslimin, di antaranya adalah shalat jum'at dan shalat berjamaah di masjid. Hal ini membuat MUI dan PP Muhammadiyah mengeluarkan fatwa tentang petunjuk ibadah, khususnya ibadah yang melibatkan banyak orang yang berkumpul di suatu tempat, seperti shalat jum'at dan shalat berjama'ah lainnya. 


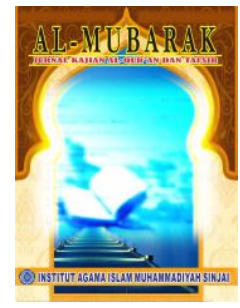

\section{Al-MUBARAK}

Jurmall Kajian Al-Quran \& Tafsir

Volume 5, No. 1, 2020

P-ISSN: 2548-7248

E-ISSN: 2715-5692

Homepage : http://journal.iaimsinjai.ac.id/indeks.php/al-mubarak

Fatwa atau petunjuk pelaksanaan ibadah shalat jum'at tersebut disandarkan dan sesuai dengan hadis Nabi Saw. sebagaimana dalam teks hadis Nabi Saw berikut ini:

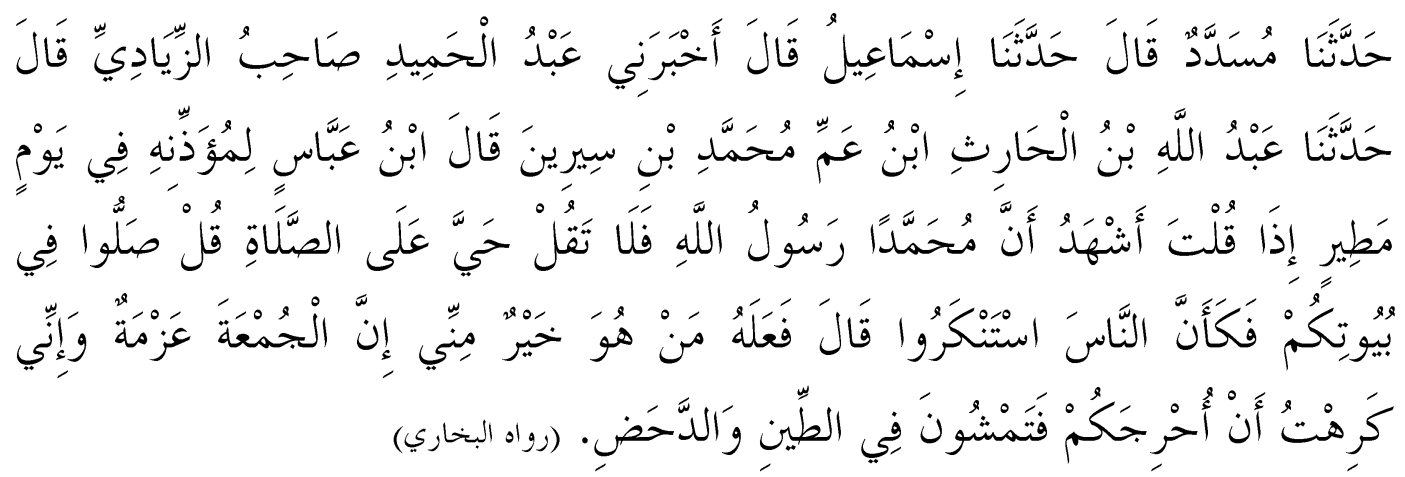

Artinya:

"Musaddad telah menceriterakan kepada kami bahwa Ismaa'il telah menceriterakan kepada kami bahwa 'Abd al-Hamid sahabat al-Ziyaadiy telah memberitahukan kepada saya, bahwa Abdullah bin al-Haris, anak pamannya Muhammad bin Sirin berkata: Ibnu 'Abbas berkata kepada Mu'azzinnya pada saat hujan: apabila kamu telah mengucapkan: Asyhadu anna Muhammadan Rasulullah, maka janganlah anda melanjutkan dengan kalimat: Hayya 'ala al-Shalah, tapi kumandangkanlah: Shalluu fi Buyuutikum (shalatlah kalian di rumah masing-masing), kemudian orangorang mengingkari (apa yang telah dilakukan oleh Ibnu 'Abbas), lalu Ibnu 'Abbas berkata baha apa yang telah saya lakukan, juga telah dilakukan juga oleh orang yang lebih baik dari diriku (yaitu Rasulullah Saw). Sesungguhnya shalat jum'at adalah suatu kewajiban dan aku tidak senang kalian keluar, kemudian berjalan di tanah yang berlumpur. (HR. Bukhari).

Hadis di atas diriwayatkan di dalam kitab Shahih Bukhari dan kualitasnya

shahih, seluruh periwayatnya tsiqah (adil dan dhabit) dan jalur sanadnya pun bersambung (ittishal sanad). Hadis tersebut menjelaskan bahwa Ibnu 'Abbas menyampaikan kepada mu'azzin-nya bahwa jika terjadi hujan lebat yang mengakibatkan jalanan penuh air dan berlumpur, agar setelah mengumandangkan Asyhadu anna Muhammadan Rasulullah, maka janganlah menyambung dengan kalimat Hayya 'ala al-Shalah, tapi diganti dengan kalimat Shalluu fi Buyuutikum (shalatlah kalian di rumah masing-masing). Ini menunjukkan bahwa jalanan yang berair dan berlumpur akibat hujan lebat sehingga menyulitkan atau bahkan mungkin dapat membahayakan orang menuju ke masjid untuk melaksanakan shalat jum'at (sebagai suatu kewajiban bagi kaum muslimin), maka kewajiban 


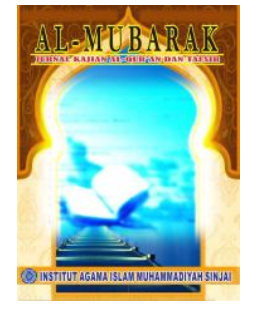

Al-MUBARAK

Jurmall Kajian Al-Quran \& Tafsir

Volume 5, No. 1, 2020

P-ISSN: 2548-7248

E-ISSN: 2715-5692

Homepage : http://journal.iaimsinjai.ac.id/indeks.php/al-mubarak

melaksanakan shalat jum'at gugur dan dapat diganti dengan shalat zhuhur di rumah masing-masing.

Tindakan yang dilakukan oleh Ibnu 'Abbas tersebut ditolak dan diingkari oleh sebagian orang dan seolah-olah Ibnu Abbas telah melakukan suatu hal yang baru dan tidak berdasar. Kemudian Ibnu 'Abbas menjawab penolakan sebagian dari mereka dengan menjelaskan bahwa apa yang telah dilakukannya itu (mengganti kalimat Hayya 'ala al-Shalah, dengan kalimat Shalluu fi Buyuutikum), juga telah pernah diserukan atau disampaikan oleh manusia terbaik baik di dunia dan di akhirat, yaitu Rasulullah Saw.

Kejadian sebagaimana telah dijelaskan dalam hadis di atas dapat dianalogikan dengan kondisi yang dialami oleh manusia saat ini, yaitu merebaknya covid-19 yang telah menjangkiti banyak orang dan mengakibatkan banyak korban, yaitu ratusan ribu orang terinfeksi positif dan ribuan orang telah meninggal dunia karenanya. Bahkan, jika dibandingkan antara kejadian di masa Ibnu 'Abbas (sebagaimana dijelaskan dalam hadis sebelumnya) dengan kejadian saat ini (merebaknya covid-19), maka kejadian yang dialami oleh manusia sekarang ini, akibatnya jauh lebih parah karena dapat menghilangkan banyak nyawa manusia. Penyebaran virus itu begitu cepat melalui proses penularan yang mudah dan tidak mudah dideteksi.

Jadi, illat gugurnya kewajibah shalat jum'at dan shalat berjama'ah adalah berkumpul dalam satu tempat saat wabah dapat menular dan menyebar, karena hal ini dapat menambah dan dianggap dapat memperluas penyebaran wabah Covid-19 tersebut. Dan jika hal ini terjadi terus menerus, maka korban akan terus bertambah dan mata rantai penyebaran Covid-19 sangat sulit untuk dihentikan. Karena itu, baik pemerintah, maupun MUI telah melarang dengan keras untuk berkumpul, termasuk dalam beribadah. Karena itu, MUI telah mengeluarkan fatwa tentang petunjuk beribadah, bagi kaum muslim, seperti terlihat pada Surat Keputusan Nomor 14 tahun 2020 yang dirilis pada Senin (16/03) sebagai berikut:

a. Setiap orang wajib melakukan ikhtiar menjaga kesehatan dan menjauhi setiap hal yang diyakini dapat menyebabkannya terpapar penyakit, karena hal itu 


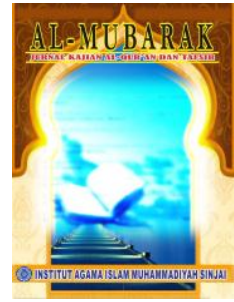

\section{Al-MUBARAK}

Jurnal Kajian Al-Quran \& Tafsir

Volume 5, No. 1, 2020

P-ISSN: 2548-7248

E-ISSN: 2715-5692

Homepage : http://journal.iaimsinjai.ac.id/indeks.php/al-mubarak

merupakan bagian dari menjaga tujuan pokok beragama (al-Dharuriyat alKhams).

b. Orang yang telah terpapar virus Corona, wajib menjaga dan mengisolasi diri agar tidak terjadi penularan kepada orang lain. Baginya shalat Jumat dapat diganti dengan shalat zuhur di tempat kediaman, karena shalat jumat merupakan ibadah wajib yang melibatkan banyak orang sehingga berpeluang terjadinya penularan virus secara massal. Baginya haram melakukan aktifitas ibadah sunnah yang membuka peluang terjadinya penularan, seperti jamaah shalat lima waktu/ rawatib, shalat Tarawih dan Ied di masjid atau tempat umum lainnya, serta menghadiri pengajian umum dan tabligh akbar.

c. Orang yang sehat dan yang belum diketahui atau diyakini tidak terpapar COVID-19, harus memperhatikan hal-hal sebagai berikut:

1. Dalam hal ia berada di suatu kawasan yang potensi penularannya tinggi atau sangat tinggi berdasarkan ketetapan pihak yang berwenang maka ia boleh meninggalkan salat Jumat dan menggantikannya dengan shalat zuhur di tempat kediaman, serta meninggalkan jamaah shalat lima waktu/rawatib, Tarawih, dan Ied di masjid atau tempat umum lainnya.

2. Dalam hal ia berada di suatu kawasan yang potensi penularannya rendah berdasarkan ketetapan pihak yang berwenang maka ia tetap wajib menjalankan kewajiban ibadah sebagaimana biasa dan wajib menjaga diri agar tidak terpapar virus Corona, seperti tidak kontak fisik langsung (bersalaman, berpelukan, cium tangan), membawa sajadah sendiri, dan sering membasuh tangan dengan sabun.

d. Dalam kondisi penyebaran COVID-19 tidak terkendali di suatu kawasan yang mengancam jiwa, umat Islam tidak boleh menyelenggarakan shalat jumat di kawasan tersebut, sampai keadaan menjadi normal kembali dan wajib menggantikannya dengan shalat zuhur di tempat masing-masing. Demikian juga tidak boleh menyelenggarakan aktifitas ibadah yang melibatkan orang banyak dan diyakini dapat menjadi media penyebaran COVID-19, seperti jamaah shalat lima waktu/ rawatib, shalat Tarawih dan Ied di masjid atau tempat umum lainnya, serta menghadiri pengajian umum dan majelis taklim. 


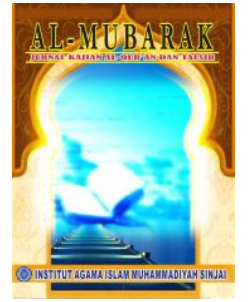

\section{Al-MUBARAK}

Jurmall Kajian Al-Quran \& Tafsir

Volume 5, No. 1, 2020

P-ISSN: 2548-7248

E-ISSN: 2715-5692

Homepage : http://journal.iaimsinjai.ac.id/indeks.php/al-mubarak

e. Dalam kondisi penyebaran COVID-19 terkendali, umat Islam wajib menyelenggarakan shalat Jumat.

f. Pemerintah menjadikan fatwa ini sebagai pedoman dalam upaya penanggulangan COVID-19 terkait dengan masalah keagamaan dan umat Islam wajib mentaatinya.

g. Pengurusan jenazah (tajhiz janazah) terpapar COVID-19, terutama dalam memandikan dan mengkafani harus dilakukan sesuai protokol medis dan dilakukan oleh pihak yang berwenang, dengan tetap memperhatikan ketentuan syariat. Sedangkan untuk menshalatkan dan menguburkannya dilakukan sebagaimana biasa dengan tetap menjaga agar tidak terpapar COVID-19.

h. Umat Islam agar semakin mendekatkan diri kepada Allah dengan memperbanyak ibadah, taubat, istighfar, dzikir, membaca Qunut Nazilah di setiap shalat fardhu, memperbanyak shalawat, memperbanyak sedekah, dan senantiasa berdoa kepada Allah SWT agar diberikan perlindungan dan keselamatan dari musibah dan marabahaya (doa daf'u al-bala'), khususnya dari wabah COVID-19.

i. Tindakan yang menimbulkan kepanikan dan/atau menyebabkan kerugian publik, seperti memborong dan menimbun bahan kebutuhan pokok dan menimbun masker hukumnya haram.

Dengan demikian, dapat dipahami bahwa keputusan MUI di atas tidak bertentangan atau sejalan dengan hadis Nabi Saw. Oleh karena itu, tidak ada alasan bagi kaum muslimin untuk tidak setuju dan wajib mematuhi keputusan MUI tersebut.

Namun, masih ada sebagian diantara mereka yang belum dapat menerima keputusan MUI itu. Mereka tetap melaksanakan shalat jum'at dan berjama'ah di masjid. Mereka berpegang dan beralasan pada sebuah hadis yang menjelaskan bahwa orang yang selalu meramaikan atau berjamaah di masjid, baik shalat jum'at ataupun shalat berjamaah lainnya, niscaya Allah Swt akan melindungi dan menjauhkan penyakit itu dari dirinya. Teks hadis tersebut adalah sebagai berikut:

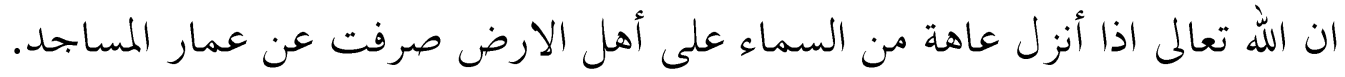




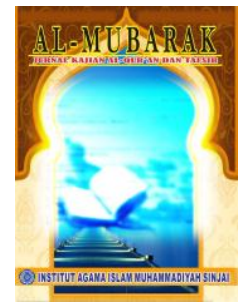

Al-MUBARAK

Jurmall Kajian Al-Quran \& Tafsir

Volume 5, No. 1, 2020

P-ISSN: 2548-7248

E-ISSN: 2715-5692

Homepage : http://journal.iaimsinjai.ac.id/indeks.php/al-mubarak

Artinya:

"Sesungguhnya apabila Allah Swt menurunkan penyakit dari langit kepada penduduk bumi, niscaya Allah Swt akan menjauhkan penyakit itu dari orang-orang yang meramaikan masjid."

Hadis di atas dijadikan pegangan oleh sebagaian ummat Islam. Mereka yakin bahwa dengan meramaikan atau shalat berjamaah di masjid, setiap waktu shalat, maka Allah Swt akan melindungi dan menjauhkan diri mereka dari wabah apapun, termasuk covid-19.

Setelah ditelusuri, hadis di atas tidak ditemukan di dalam sembilan (9) kitab hadis yang mu'tabar. Karena itu, teks hadis tersebut dikutip dari kitab Silsilah Hadits Dha'if dan Maudhu', karya Nashir al-Din al-Albani, 1851, Juz. IV. Menurut al-Albani, kualitas hadis tersebut dhaif atau lemah, khususnya dari segi sanad. Adapun dari segi matan, kandungannya pun tidak sejalan dengan QS alAnfal: 25 .

Hadis di atas menjelaskan bahwa musibah itu diturunkan oleh Allah Swt hanya kepada orang-orang yang zhalim, sedangkan orang-orang yang shalih seperti mereka yang taat shalat berjamaah di masjid dihindarkan dari musibah tersebut. Hal ini bertentangan dengan QS al-Anfal: 25 yang menjelaskan bahwa Allah Swt menurunkan musibah pada suatu kaum secara umum, baik yang zhalim maupun yang shalih. Karena kandungan hadis di atas bertentangan dengan QS alAnfal: 25, maka kualitas hadis di atas dari segi matan-pun dapat dinilai dhaif atau lemah. Dengan demikian, hadis di atas tidak dapat dijadikan pegangan atau sandaran dalam beramal.

\section{Simpulan}

Berdasarkan uraian sebelumnya, maka kesimpulan yang dikemukakan sebagai berikut: Pertama, wabah atau virus yang telah menjangkiti banyak orang saat ini, telah terjadi pada masa sebelumnya, hanya bentuknya yang berbeda. Istilah wabah yang digunakan dalam hadis Nabi Saw adalah thaa'uun, yang artinya wabah atau virus. Cara mengatasinya-pun sudah dijelaskan di dalam hadis Nabi Saw, yaitu tidak mendatangi atau tidak masuk ke dalam daerah yang terkena wabah dan tidak keluar dari daerah tersebut (lockdown), kecuali ada kepentingan yang mendesak, itupun harus hati-hati, menggunakan masker, dan menjaga jarak 


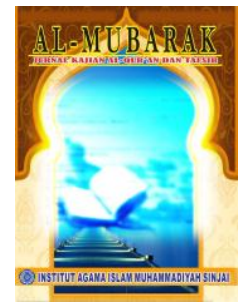

\section{Al-MUBARAK}

Jurnal Kajian Al-Quran \& Tafsir

Volume 5, No. 1, 2020

P-ISSN: 2548-7248

E-ISSN: 2715-5692

Homepage : http://journal.iaimsinjai.ac.id/indeks.php/al-mubarak

dengan orang lain atau social distancing. Kedua, salah satu bentuk penyebaran covid-19 yang cepat dan meluas adalah berkumpul atau berjama'ah, karena itu ibadah yang membutuhkan kumpulan orang atau berjama'ah seperti shalat jum'at atau shalat berjama'ah lainnya, kewajibannya digugurkan dan pelaksnaannya dilaksanakan di rumah masing-masing. Dalam hadis Nabi Saw tersebut, hanya tanah berair dan berlumpur yang terjadi, kewajiban shalat jum'at digugurkan, apalagi jika covid-19 yang terjadi. Tanah yang berair dan berlumpur tidak mengancam jiwa manusia, tapi hanya mendatangkan kesulitan. Sedangkan penularan covid-19 sangat membahayakan dan mengancam jiwa manusia. Karena itu, kewajiban shalat jum'at-pun lebih digugurkan lagi.

\section{Daftar Pustaka}

Abu Husain Ahmad bin Faris. (1994). Mu'jam al-Maqayis al-Lughah. Bairut: Dar al-Fikr.

Al-Albani, Nashir al-Din. (1994). Silsilah al-Ahadits al-Dha'ifah wa alMaudhu'ah,. telah diterjemahkan oleh A.M. Basalamah dengan judul: Silsilah Hadits Dha'if dan Maudhu'. Jakarta: Gema Insani Press.

Atabik Ali dan Amad Zuhdi Muhdlor. (1996). Kamus Kontemporer: ArabIndonesia. Yogyakarta: Multi Karya Grafik.

Al-Bukhârî, Abî 'Abdillâh Muhammad bin Ismâ‘îl. (T.th.) S Sahîh $\underline{h}$ al-Bukhârî. Indonesia: Maktabah Dahlân.

Departemen Pendidikan dan Kebudayaan. (1993). Kamus Besar Bahasa Indonesia. Jakarta: Balai Pustaka.

al-Fairuz Aabadi, Majd al-Din Muhammad bin Ya'qub. (2008). Al-Kamuus alMuhiith. al-Qahirah: Daar al-Hadits.

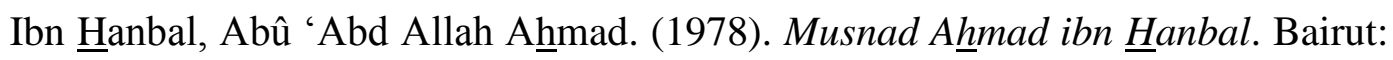
Maktabat al-Islâmîyyah.

Al-Munjid al-Abjadiy. (1967). Bairut: Dar al-Masyriq.

Nur Azizah, Khadijah. (2020). detikhealth, internet, Kamis, 12 Maret. 00.27 WIB.

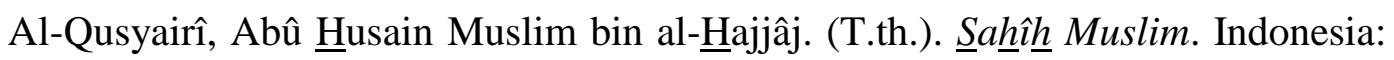
Toha Putra. 


\section{Al-MUBARAK}

Jurmal Kajian Al-Quran \& Tafsir

Volume 5, No. 1, 2020

P-ISSN: 2548-7248

E-ISSN: 2715-5692

Homepage : http://journal.iaimsinjai.ac.id/indeks.php/al-mubarak

Al-Sijistânî, Abû Dâud Sulaimân Ibn al-Asy‘ats. (T.th.). Sunan Ab̂u Dâud, Indonesia: Toha Putra.

Al-Turmudzî, Muhammad bin 'Îsâ Abû 'Îsâ. (T.th.). Sunan al-Turmudzî. Beirut: Dâr Ihyâ' al-Turâts. 